\title{
The Impact of Corporate Governance on the Cost of Equity for Russian Companies in the Ohlson Model
}

\section{Adil Khassanov $\square$}

PG student, Faculty of Economic Sciences

$\underline{\text { ORCID }}$

E-mail: adil_khassanov@mail.ru

National Research University Higher School of Economics,

Moscow, Russia

Journal of Corporate Finance Research, Vol. 15, No. 1, pp. 5-18 (2021)

For citation: Khassanov, A. (2021) «The Impact of Corporate Governance on the Cost of Equity for Russian Companies in the Ohlson Model», Journal of Corporate Finance Research / Корпоративные Финансы | ISSN: 2073-0438, 15(1), cс. 5-18. doi: 10.17323/j.jcfr.2073-0438.15.1.2021.5-18.

Received 15 October 2020 | Peer-reviewed 23 October 2020 | Accepted 24 October 2020 


\section{Abstract}

The purpose of this paper is to identify key indicators of corporate governance that affect the market value of Russian companies. To this end, we examine the possibility of modifying the Ohlson model of evaluating stock price dynamics in public companies, by adding corporate governance variables that may affect market value.

The study consists of the following stages: the key points of the Ohlson economic model are described, empirical works that demonstrate corporate governance as a factor in assessing the value of companies are presented, and the significance of the modified Ohlson model for the Russian market is evaluated.

The novelty of our methodology is represented in the prioritisation of our "other information" parameter, which is a combination of forecast analytical data and corporate governance indicators. Through analysis of panel data, we estimate differences in the predicted net profit indicator, calculated as the average of analyst forecasts for an individual company for a financial year, and the actual net profit. Corporate governance is represented by the percentage of board members holding professional certificates and licenses, the average term of board of directors members, the share of independent members on the board of directors, the share of independent members in the audit committee, the proportion of women on the board of directors, and the size of the board of directors.

Our results indicate dependence of share prices on the dynamics of the book value of equity, abnormal profits, the share of board members holding professional qualifications, the difference between the actual net profit and the forecast net profit of companies, and the level of gender diversification in the board of directors. The results of our analysis of deviations in average stock prices are comparable to the findings of existing literature examining the markets of Europe, Latin America and Africa.

Keywords: Ohlson model, valuation, corporate governance, board of directors, fixed effects model, emerging markets 


\section{Introduction}

When investors create their investment portfolios the share proportion varies depending on their attitude to risk. Shares from the investment portfolio may have a greater rate of return than government and corporate debt securities. Optimisation of the risks related to shares as a financial assets class is of importance. Consequently, a multivariate analysis is necessary to assess stock prices in the investor's portfolio.

The purpose of the present research paper is to define the key indicators of corporate governance which influence the market value of Russian companies by means of modifying the Ohlson model.

To achieve the above purpose, we addressed the following tasks:

1) identification of the key points of the Ohlson economic model;

2) consideration of empirical evidence of research papers which demonstrate corporate governance as a factor of assessing the value of companies (including those related to the Ohlson model);

3) adaptation of the Ohlson model to the Russian market on the basis of available information.

The methodological foundation of this study is the academic paper by J. Ohlson Earnings, titled 'Book Values and Dividends in Equity Valuation'. In that paper, the author considers the influence of financial and "other" information on dynamics of stock prices of public companies. The overwhelming majority of the studied academic papers which tested the Ohlson model confirm the validity of its application and are indicative of research relevance.

Theoretical problem definition. The traditional approaches to company valuation are the income (cash flow discounting model), comparative (market multiplier method), and cost approaches. Each of them has its limitations and drawbacks which result in inconsistency of assessments due to the fact that it is difficult to forecast future cash flows, difficult to find analogues, and to take into consideration only retrospective information. In addition to the above approaches, alternative methods have been developed. One of them is the Ohlson model, which considers actual market data. It is based on calculations presented in financial statements and takes into consideration the key future changes of indicators. The interrelations presented in the research belong to the study of corporate finance theory, and in particular to corporate governance issues (agency conflicts, for instance), accounting theory, and preconditions which lay the foundation of the equity capital cost estimation model.

The empirical component is integrated in the paper by means of analysis of a well-balanced data panel by comparing the evaluations of model coefficients to deterministic (fixed) and random effects and pooled regression.
The "other information" variable is a combination of complementary factors: forecast analytical data and corporate governance indicators.

The academic novelty of the paper consists in the fact that its empirical study was the first to reveal the influence of corporate governance on stock prices of public companies incorporated in Russia by modifying the Ohlson model.

A conclusion was made that there is a direct dependence of share prices on the dynamics of the book value of equity, abnormal profits and the share of board members holding professional certificates and licenses. At the same time an inverse dependence of share prices on the difference between the forecast net profit and the actual net profit of companies and on the level of gender diversification in the board of directors was shown.

This paper consists of three sections: literature review, methodological approach and empirical evidence.

\section{Literature Review}

Corporate governance, in the broadest sense, is understood as a system of relationships between a company's management, its board of directors, shareholders and other concerned parties aimed at pursuing the same interests ${ }^{1}$. In this context it is important to take into consideration not just the exercising but also the separation of property rights and rights of corporate operations control. One paper describes an existing divergence of interests of shareholders and managers in corporate governance theory which has an indirect impact on the increase of costs for delegation of powers in the company [1]. Corporate governance may be used to settle conflicts in the principal - agent context. Corporate governance mechanisms are divided into internal mechanisms (control of operations by the board of directors, distribution of shares among managers, managers' remuneration depending on financial performance) and external ones (corporations law, arrangement of corporate control, and financial markets regulation) [2].

In foreign practice, there are the Anglo-US, German, and Japanese corporate governance models. In the Anglo-US model the board of directors plays the key role, the company's interests and its shareholders' interests are of the same importance, and the operations management is delegated to managers as "agents". The German model is characterised by a rather highly concentrated equity holding structure. Banks play an important role in this model by performing control through their representatives in the board of directors. In the Japanese corporate governance model government plays a significant part, equity is concentrated in the hands of institutional investors and the board of directors is of almost no importance [3]. In their turn, Russian researchers also paid attention to the agency conflicts problem and proposed the method of financial management quality evaluation for oil and gas corpora- 
tions as an instrument of their prevention by means of analysis of an interdependent indicators' complex and use of three information bases. It should be noted that final assessments are made according to two scenarios (growth and crisis), thus, providing higher adaptivity against the background of economic fluctuations [4].

Various aspects of corporate governance are widely used in the papers dedicated to corporate finance. Applying econometric models, foreign and Russian researchers study the influence of corporate governance factors on the system of senior managers' remuneration, equity value, efficiency of companies etc.

It was revealed in the paper dedicated to American companies (5,530 observation points within the period of 1991 to 2012) that as long as the board of directors grows larger, and the share of independent members and women on the board of directors increases, the percentage of the shares held by the board of directors decreases, and duties in several boards of directors are performed simultaneously, the use of non-financial indicators of operations as indicators of senior management remuneration is encouraged [5].

The role of women on boards of directors has been studied in a series of foreign papers. In particular, a major study was carried out on the basis of data from 87 academic papers (published in 1987-2015) in 20 countries (approximately 27 thousand companies) [6]. The factor of women on the board of directors was measured by the following parameters: proportion of women, and number of women or a certain number of women on the board of directors. The corporate governance quality, defined by the external rating, gender diversification of human resources, share of charity expenses, and presence of the code of ethics, was used as a dependent variable. The regression analysis of the random effects model established that an increase of the number of women on the board of directors on average results in improvement of the corporate governance quality, and it is greater in the companies located in the countries with a higher level of shareholder protection and a more pronounced level of gender equality.

Influence of the share of independent members of the board of directors on corporate performance is considered against the background of the presence of women on the board of directors [7]. After the authors applied the generalised method of moments to analyse data from 3,876 companies from 47 countries (13 companies were from Russia) they made the conclusion that companies with a greater number of women on the board of directors show a higher Tobin's Q and return on assets. Therefore, independent members of the board of directors play no significant role in this issue until the board of directors becomes diversified from the gender point of view.

Ambiguity of evaluation of influence of the share of independent directors on the board on Tobin's Q is also observed in the Swedish market [8]. The common effect of increasing the share of independent board members was negative, while a significant amount of directors included in the selection were simultaneously involved in similar business. That could produce a negative impact on corporate performance due to risks of information leakage and intra-industry competition.

From the perspective of the considered topic, the research dedicated to the importance of adding a description of the personal qualities of members of the board of directors to the analysis of corporate governance draws attention [9]. Using data from the Italian market (93 companies for 2014-2016) the authors manually gathered the following information on board members: nationality, education, foreign training, acquired qualifications, and industry experience. Then they built two regression models with fixed effects (dependent variable - Tobin's Q). They concluded that nationality and education had no influence on the model, however, an increase of Tobin's Q was explained by the fact that the board of directors has more directors with business qualifications and experience in strategic consulting.

Early research for Russian companies was based on revealing the dependence between the corporate governance score and market value $[10 ; 11]$. In the opinion of a range of authors, the corporate governance factor has been playing a rather significant role in the assessment of Russian companies' performance [12]. Later papers reveal more novel approaches. Regardless, the paper studies the influence of the share of independent directors on the board, the percentage of shares held by management and government participation in equity on Russian companies with diversification and focusing strategies. It was discovered that diversified companies increase government ownership of their shares, and the share of independent directors on the board facilitates growth of their value [13].

In view of the experience of Russian studies in assessing the influence of corporate governance on the equity value of countries from emerging regions, Latin America is also of interest [14]. Applying an approach which takes into consideration companies' exposure to country risk (lambda approach) the authors of the cited study calculated equity values in 90 companies from Brazil, Mexico, Chile, Colombia, and Peru. The variables which describe corporate governance comprised three author's indexes: disclosure, the board of directors, shareholder rights, and ownership structure. The first index is made on the basis of the information on the standard used to disclose corporate financial statements, whether the auditor belongs to the Big Four, whether remuneration of the senior management is disclosed, whether a clean audit report has been obtained, and whether information is available in other languages. The second index structure is indicative of a continuous operation of the audit committee, the possibility of overlapping of the executive director's position with that of the chairman of the board of directors, the number of board of directors' members, the share of independent members in the board of directors, and simultaneous membership of several directors in the board for more than two years. The third index takes into consideration 
the fact of whether majority shareholders own more than $70 \%$ of voting stocks, whether non-voting stocks amount to less than $20 \%$ of corporate capital, whether companies issue only voting shares, whether distribution of voting shares is proportionate to the number of shares held by a majority shareholder, and whether an institutional investor owns an equity share exceeding 5\%. The regression analysis revealed a stable dependency between the corporate governance quality and capital cost in Latin America. A study of the effect produced by the above indexes on company value showed that disclosure has the greatest impact, the second index is significant at a $10 \%$ level, and the third index is insignificant, while the determination coefficient amounted to 0.40 .

Along with classical approaches to evaluation (income, comparative, cost approach) there are alternative ones which comprise the Ohlson model. In 1995 James Ohlson provided theoretical and methodological provisions of the model which characterised the determinants of corporate market value change [15]. The evaluation of equity value is performed by means of analysis of information taken from financial statements and other relevant data. The reference condition is no opportunity to resort to arbitration and risk-neutral investors with homogeneous expectations.

The assertion that the corporate market value may be calculated by contraction of expected dividend flows as per the public securities rate is accepted as one of the three prerequisites:

$\mathrm{P}_{\mathrm{t}}=\sum_{\tau=1}^{\infty} \frac{\mathrm{E}_{\mathrm{t}}\left[\tilde{\mathrm{d}}_{\mathrm{t}+\tau}\right]}{\left(1+\mathrm{r}_{\mathrm{f}}\right)^{\tau}}$,

where $\mathrm{P}_{\mathrm{t}}$ - the corporate market value at the moment $\mathrm{t}$; $d_{t}$ - amount of net dividends paid at the moment $t$; $r_{f}$ - risk-free interest rate (as a non-stochastic variable);

$\mathrm{E}[$.$] - expectation operator at the moment \mathrm{t}$.

The second prerequisite (of clean surplus relation) exemplifies the fact that, provided the data presented in financial statements is complete, the book value of equity in the current period is equivalent to the book value of the previous period and net profit and dividends of the current period:

$b v_{t}=b v_{t-1}+x_{t}-d_{t}$,

where $b v_{t}$ - equity book value;

$x_{t}-$ net profit for the period of $(t-1, t)$;

$d_{t}-$ net dividends paid as at the moment $t$.

The abovementioned variable corresponds to the book value of net assets calculated as a difference between corporate assets and liabilities.

At the same time, it is important to define the abnormal profit $\left(x_{t}^{a}\right)$ which equals the difference between the

amount of net profit and equity book value of the previous period for the discount rate: $\mathrm{x}_{\mathrm{t}}^{\mathrm{a}}=\mathrm{x}_{\mathrm{t}}-\mathrm{r}_{\mathrm{d}} \cdot \mathrm{b} \mathrm{v}_{\mathrm{t}-1} \cdot$

The discount rate is the rate based on the CAPM methodology with a known Beta coefficient, company and market profitability.

Based on the information above, one can make the conclusion that resolutions related to current and expected dividend payouts and the amount of the current and future profits are independent.

The third prerequisite describes characteristics of abnormal profits and may be presented as follows:

$\tilde{\mathrm{x}}_{\mathrm{t}+1}^{\mathrm{a}}=\omega \mathrm{x}_{\mathrm{t}}^{\mathrm{a}}+v_{\mathrm{t}}+\tilde{\varepsilon}_{1, \mathrm{t}+1}$
$\tilde{v}_{\mathrm{t}+1}=\gamma v_{\mathrm{t}}+\tilde{\varepsilon}_{2, \mathrm{t}+1}$,

where $v_{\mathrm{t}}$ - "other information" indicator: data collection not included in the current financial statements but influencing future statements;

$\gamma$ - constant parameter for $v_{\mathrm{t}}(0 \leq \gamma<1)$;

$\omega$ - parameter of abnormal profits constancy $(0 \leq \omega<1)$;

$\tilde{\varepsilon}_{\mathrm{t}, \mathrm{t}+1}$ - chance observation errors with zero variance.

Approximation of the "other information" parameter is one of the key objectives of this research. The definition of "other information" comprises information not taken into consideration in the current financial statements, which nevertheless has a significant influence on the successive statements [16]. The general wording urged researchers to perform approximation calculations. In a series of papers, the authors devise the "other information" parameter by use of analysts' consolidated forecasts concerning profits and net income of a future period, by adding abnormal dividends, various multipliers, macroeconomic and industry-specific control variables. Other authors ignore the "other information" for simplification purposes $[17 ; 18]$.

See below a review of empirical research of the Ohlson model for the last few years, including adding of corporate governance factors.

The academic novelty of the paper [19] resides in the fact that the authors include corporate governance indicators in the Ohlson model in the Taiwanese market and its explanatory power in forecasting quoted prices for 219 nonfinancial companies. The corporate governance is expressed through 11 variables which comprise a proportion of shares held by the board members, majority shareholder's ownership share, the percentage of shares owned by individual persons, the right of the largest voting shareholder, and the percentage of voting shareholders concerning cash flows. Cointegration of the market value and book value with abnormal profits not taking into consideration corporate governance amounts to $48 \%$, and if this parameter is taken into consideration it may be $99 \%$. The influence of corporate governance on the market value of companies in the Ghanian market was studied in paper [20]. The variables characterising corporate governance comprise the size of the board of directors, overlapping of the executive director's position with that of the board of directors' chairman, and the percentage 
of independent directors on the board. The smaller the board of directors, the higher the company's market value is. A joint appointment of the same person to the position of the executive director and the chairman of the board of directors results in growth of the quoted price. Independence of the board members has no significant impact on the company value. The determination coefficient of the obtained model amounted to 0.67 .

A major study (over 1,000 companies for 8 consecutive years) of the Ohlson model was dedicated to Latin American markets [21]. In spite of ignoring the "other information" variable and the replacement of abnormal profits with net profit, the authors make the conclusion that the Ohlson model explains dependence of share prices on regressors in Mexico, Chile, Bermuda and Cayman Islands; with certain limitations - i.e. in Brazil, Panama and Peru - and does not explain it in the markets of Venezuela, Colombia, and Argentina.

The empirical testing of corporate governance influence on the corporate market value in the Brazilian market is described in paper [22]. The research methodology comprises panel data analysis for 90 companies between 2004 and 2010 (630 observation points). The authors compared various models and the random effects model turned out to be the optimal one. Corporate governance, expressed through the following approximating indicators, influences the shares' market value: ownership structure (government- or family-owned with over 35\% held by the dominant shareholder), and percentage owned by the largest shareholder. The family and government ownership structures are considered to be the most acceptable ones from the point of view of value because such companies have the highest level of information control. The implementation of corporate governance factors in the Ohlson model increases the determination coefficient from 0.42 to 0.49 .

Expressing the "other information" through the Piotroski score which is a statistically significant indicator in the model and characterises corporate financial standing was an ingenious solution offered in the paper, testing the Ohlson model in the Mexican market from 2005 to 2011 [23]. The absolute and relative value of return on assets, amount of operational cash flow, dynamics of gross profit margin, asset turnover, credit leveraging, and day-to-day liquidity take on a binary value. The regressors comprise the Piotroski score for the current and previous periods and the last year's stock price with a 3 months' lag.

The authors revealed a difference in the explanatory power of the equity book value and earnings per share as of the reporting date depending on the rate of return of Chinese companies [24]. Low profit companies showed a low determination coefficient which reached the maximum level (over 40\%) at an average profitability. The authors also indicate an interrelation of regressor coefficients: high profit companies get profit from share performance which exceeds the equity book value, and with the maximum determination coefficient the difference between them is minimal.
The paper cited at [25] offers an interpretation of growth of the capability of financial indicators to explain the dynamics of the market value by transfer of Canadian companies to IFRS. It was established that implementation of IFRS resulted in growth of the determination coefficient from 55 to $76 \%$. In addition, the authors verified the model for stability excluding from the selection financial organisations and confirmed their conclusions which were similar for European analogues.

The "other information" parameter is described by human capital indicators for the Turkish market from 2004 to 2014 [26]. Human capital comprises expenses per an employee which consist of a salary, bonuses and other social payments, and earnings per an employee. The authors found out the following dependency: the reason for change of share price by 0.003 and 0.151 monetary units may be dynamics of earnings and expenses for employees per 1,000 monetary units.

The Kuwaiti market is unique, due the requirement that two external audit organisations are required to conduct a company audit [27]. According to this requirement the authors used the auditor composition as the "other information" parameter. Their conclusions seem obvious: the biggest adjusted determination coefficient (63\%) was obtained for companies whose statements had been audited by two 'Big Four' auditing companies, and the smallest for those companies whose statements had been audited by two local auditors.

Dynamics of the market value of Chinese companies tends to be affected by historical (amount of annual dividends, net profit, equity book value) as well as forecasting information (expected dividends) [28]. The author at [28] makes the conclusion that in spite of a high adjusted determination coefficient (79\%) the Ohlson model may bring forward revaluation of the corporate market value.

A recent comparison of indicators from interim and annual financial statements against the background of verification of the Ohlson model was performed focusing on the RSA market [29]. In spite of the fact that these indicators comprise only the basic parameters offered by Ohlson, it should be noted that the relevant specifications indirectly measure the level of investors' confidence in the audited annual reports. In the model specification (which uses interim indicators) net profit is shown to be insignificant due to within-year fluctuations, unlike in the specification which uses indicators from annual reports where the model itself and evaluations of coefficients of all regressors are of significance.

In the Turkish market, the transfer to IFRS triggered research on the influence of profit and net assets on stock prices from 2001 to 2008 [30]. The selection was divided into two sub-selections: before and after implementation of IFRS. In the pooled regression model, the adjusted determination coefficient from the second selection surpassed the results of the first one (57 and 32\%). So, the authors made the conclusion that IFRS has a positive impact and it is correct to use financial indicators from such statements for testing the Ohlson model. 
In research [31] the key parameter of corporate governance is the percentage of women in the top levels of management of 411 German public companies. Among other variables are included the share of board members having financial education, the share of independent board members, size of the board of directors, and membership of external auditors in the Big Four (Deloitte, KPMG, EY, PWC). A positive significant (at a $1 \%$ level) influence on the corporate market value is exerted by the share of women in top management, the size of the board of directors and membership of external auditors in the Big Four. In its turn the share of the board members with financial education and share of independent board members were insignificant. The determination coefficient of the tested model amounted to 0.31 .

The presence of influence of corporate governance on the corporate market value from ten developed European countries is shown in paper [32]. There were 18,746 observation points for the period of 2001 to 2013. Corporate governance is expressed via the dummy variable, which characterises the company's presence in the Dow Jones Sustainability Index Europe. The influence of corporate governance was significant for the region, and the determination coefficient amounted to 0.84 . However, the authors emphasise that there were inter-country differences: a company's presence in the abovementioned index turned out to be significant only in Germany and Sweden. This paper is noteworthy due to the large scale of analysed data, however, it is possible to improve the chosen approximating indicator by using internal corporate governance mechanisms.

In the SAR market, corporate governance plays an important role in company value assessment [33]. A lot of data used for analysis consisted of financial statements of 90 public companies from 2002 to 2014. The variables of corporate governance are comprised of data on the size of the board of directors, the share of independent board members, number of meetings of the board of directors within a year, level of gender and race differentiation in the board of directors, a joint appointment of the same person to the position of the executive director and the chairman of the board of directors. At a 1\% significance level, the corporate market value grows due to enlargement of the board of directors, increase of the number of the board meetings in a year and level of gender and race differentiation in the board of directors. The determination coefficient of the obtained model amounted to 0.69 .

A comparative analysis between countries was conducted from the point of view of testing the Ohlson model for the markets of China, Japan and South Korea [34]. The cluster analysis for the three markets showed a statistical significance of the model and all regressors. In the context of the markets the biggest determination coefficients are observed for the companies from South Korea, the smallest - for those from China. Evaluation of the net profit coefficient is the biggest in comparison to other regressors for the three markets, and the book value of equity for the Chinese market takes the negative sign and this is an unexpected conclusion.

The transfer of companies to IFRS was also of relevance for the authors of the paper describing the markets of France, Belgium and Germany as the most conservative ones from an accounting point of view [35]. The selection was divided into two sub-selections: before and after implementation of IFRS. An insignificant growth of the determination coefficient from 37.5 to $39.3 \%$ was observed. On this basis, the authors made the conclusion of a positive influence of the procedure of transfer to IFRS.

On the basis of the analysed publications, we can make the conclusion that testing of the Ohlson model is of much academic interest, while corporate governance plays an important role in the issue of corporate value evaluation. Therefore, considering this phenomenon from the point of view of the Russian equities market is highly important.

\section{Research Methodology}

The financial information on the companies available for analysis was taken from the Compustat ${ }^{2}$ data base. Empirical analysis is based on observing a series of terms which comprise the criteria for selection. Financial organisations are not considered because components of their balance sheets are in marked contrast to those of non-financial organisations. In accordance with Ohlson's paper, on an annual basis the equity book value should exceed 0 for each company within the considered time horizon. Individual discount rates calculated on the basis of CAPM were used for evaluation of abnormal profits.

In order to make a well-balanced data panel, the studied assembly of companies comprises only those companies with the quoted market price of shares available within the period of observations. Initially there were 68 public companies incorporated in Russia, however, after filtering with the $\mathrm{I} / \mathrm{B} / \mathrm{E} / \mathrm{S}$ system this number reduced to 44 . At the final stage of making the final selection, in order to prevent the possible heteroscedasticity, the financial variables were normalised to the number of shares in circulation. So, we obtained an aggregate of 31 observed companies. Testing was conducted for a well-balanced data panel which was possible, in spite of gaps in the initial data, due to application of the multiple imputation method. In this method, the missing data is restored several times, then it is integrated within the tested model specification [36]. Historical observations range from 2011 to 2018 (20082010 were excluded because a lot of companies showed a negative book value of equity). So, for the purpose of analysis of a well-balanced data panel, we present 248 observation points.

\footnotetext{
${ }^{2}$ Data base of Compustat S\&P Global. URL: https://www.spglobal.com/marketintelligence/en/?product=compustat-research-insight (available as of January of 2020, reference date: 15.03 .2020$)$.
} 
Table 1. Descriptive statistics of the tested variables

\begin{tabular}{|c|c|c|c|c|c|}
\hline Variable & $\begin{array}{l}\text { Number of } \\
\text { observations }\end{array}$ & Mean value & $\begin{array}{l}\text { Standard } \\
\text { deviation }\end{array}$ & Minimum & Maximum \\
\hline $\mathrm{P}$ & 248 & 25.65 & 3.65 & 0.01 & 275.07 \\
\hline $\mathrm{Bv}$ & 248 & 18.98 & 2.93 & 0.04 & 107.48 \\
\hline Abpr & 248 & 3.22 & 1.31 & -2.94 & 22.27 \\
\hline Foni & 248 & 5.85 & 1.48 & 0.06 & 11.21 \\
\hline Bss & 248 & 41.85 & 2.87 & 25.56 & 82.00 \\
\hline $\mathrm{Abt}$ & 248 & 4.84 & 0.32 & 1.22 & 9.20 \\
\hline Ibm & 248 & 35.21 & 2.77 & 5.56 & 93.75 \\
\hline Aci & 248 & 72.16 & 1.73 & 20.00 & 100.00 \\
\hline Bgd & 248 & 7.44 & 0.98 & 0.00 & 25.00 \\
\hline Bsz & 248 & 7.55 & 0.11 & 5.00 & 16.00 \\
\hline
\end{tabular}

Source: compiled by the author.

Table 2. Correlation matrix of variables

\begin{tabular}{|c|c|c|c|c|c|c|c|c|c|c|}
\hline Variables & $\mathbf{P}$ & bv & abpr & foni & Bss & $\mathbf{a b t}$ & ibm & aci & bgd & bsz \\
\hline P & 1.00 & & & & & & & & & \\
\hline $\mathrm{Bv}$ & 0.61 & 1.00 & & & & & & & & \\
\hline Abpr & 0.42 & 0.32 & 1.00 & & & & & & & \\
\hline Foni & 0.56 & 0.22 & 0.67 & 1.00 & & & & & & \\
\hline Bss & 0.19 & 0.15 & -0.06 & -0.04 & 1.00 & & & & & \\
\hline $\mathrm{Abt}$ & 0.12 & 0.37 & 0.01 & 0.16 & 0.08 & 1.00 & & & & \\
\hline Ibm & 0.02 & -0.03 & -0.01 & -0.03 & 0.03 & 0.01 & 1.00 & & & \\
\hline Aci & 0.02 & -0.06 & -0.04 & -0.09 & -0.06 & -0.19 & 0.39 & 1.00 & & \\
\hline Bgd & 0.18 & 0.12 & 0.24 & 0.26 & -0.12 & -0.17 & -0.01 & -0.07 & 1.00 & \\
\hline Bsz & 0.09 & 0.11 & 0.20 & 0.22 & -0.18 & -0.03 & 0.13 & 0.12 & 0.33 & 1.00 \\
\hline
\end{tabular}

Source: compiled by the author.

Our analysis of panel data is justified because this analysis method is the leading one in the studied papers from the point of view of the testing of the Ohlson model. Additionally, the panel data (when compared to time series and cross selection) shows a high aggregation, efficiency, a larger number of degrees of freedom and a smaller indicators collinearity [39; 40]. From the Stata econometric package, we obtained assessments of coefficients in fixed (deterministic) effects models and random effects models, and in the pooled regression applying a common least-square method.

We should mention that the "other information" parameter is a combination of complementary factors: forecasting analytical data and corporate governance indicators. In particular, the first one is evaluated as a difference between the forecasting net profit indicator calculated as the arithmetic mean of analysts' forecasts for a certain company for a financial year downloaded from $\mathrm{I} / \mathrm{B} / \mathrm{E} / \mathrm{S}^{3}$ system and the actual net profit of companies. In its turn, corporate governance comprises the following parameters:

1) percentage of board members holding professional certificates and licenses;

2) average term of board of directors members;

3) share of independent members on the board of directors;

4) share of independent members in the audit committee;

5) proportion of women on the board of directors;

6) size of the board of directors.

\footnotetext{
${ }^{3}$ Data base Institutional Brokers' Estimation System Thomson Reuters. URL: https://financial.thomsonreuters.com/en/products/data-analytics/ company-data/ibes-estimates.html (available as of January 2020, reference date: 15.03.2020).
} 
The specification of the tested model is indicative of the following dependency:

$\mathrm{P}_{\mathrm{t}}=\mathrm{a}+\alpha_{1} \mathrm{bv}_{\mathrm{t}}+\alpha_{2} \mathrm{abpr}_{\mathrm{t}}+\alpha_{3}$ foni $_{\mathrm{t}}+\alpha_{4} \mathrm{bss}_{\mathrm{t}}+$

$+\alpha_{5} \mathrm{abt}_{\mathrm{t}}+\alpha_{6} \mathrm{ibm}_{\mathrm{t}}+\alpha_{7} \mathrm{aci}_{\mathrm{t}}+\alpha_{8} \mathrm{bgd}_{\mathrm{t}}+\alpha_{9} \mathrm{bsz}_{\mathrm{t}}+\mathrm{e}_{\mathrm{t}}$,

where $P_{t}$ - company share price at the end of the $4^{\text {th }}$ month following the end of the financial year;

$\mathrm{bv}_{\mathrm{t}}$ - book value of net assets per individual share;

$\mathrm{abpr}_{\mathrm{t}}$ - abnormal profit per individual share;

foni $_{t}$ - difference between the anticipated net profit indicator and actual net profit of companies per individual share;

bss $_{t}$ - percentage of board members holding professional certificates and licenses;

$\mathrm{abt}_{\mathrm{t}}$ - average term of board of directors members;

$\mathrm{ibm}_{\mathrm{t}}$ - share of independent members on the board of directors;

$\mathrm{aci}_{\mathrm{t}}$ - share of independent members in the audit committee;

$\operatorname{bgd} d_{t}$ - proportion of women on the board of directors;

$\mathrm{bsz}_{\mathrm{t}}$ - size of the board of directors;

a - intercept regression term;

$e_{t}-$ chance observation errors.

Descriptive statistics and a correlation matrix for the tested variables are presented in Tables 1 and 2 respectively.

On the basis of the research cited at $[37 ; 38]$ the influence of regressors on prices in the fourth month following the end of the year were evaluated. There are two justifications for the above time period: first, the data verified by auditors is more trustworthy and actually it takes approximately four months to make an auditor's opinion after verification of annual financial statements. Second, the literature review above confirms that in most cases, prices for the fourth month are used to test the Ohlson model, i.e. the prices in April were taken for Russian companies. At the final stage of testing, the most relevant model specification is chosen on the basis of the results of econometric tests, and a comparison of standard errors evaluations and also the extent of deviation from the actual price of shares in April of 2019 is estimated.

\section{Empirical Evidence}

The research studies cited at $[37 ; 38]$ present coefficients with certain stability parameters of abnormal profits and "other information" for the Russian market (Table 3) which are statistically significant and differ from 0 and 1 (extremal values). The abovementioned parameters allow to adjust the model statistically to the Russian equities market.
Table 3. Autoregressive stability parameters of abnormal profits and "other information" for the Russian market

Evaluated dependence Parameters value

$$
\begin{array}{cc}
\tilde{\mathrm{x}}_{\mathrm{t}+1}^{\mathrm{a}}=\omega_{0}+\omega_{1} \mathrm{x}_{\mathrm{t}}^{\mathrm{a}}+\tilde{\varepsilon}_{1, \mathrm{t}+1} & \omega_{1}=0.67 * * * \\
\tilde{v}_{\mathrm{t}+1}=\gamma_{0}+\gamma_{1} v_{\mathrm{t}}+\tilde{\varepsilon}_{2, \mathrm{t}+1} & \gamma_{1}=0.96 * * *
\end{array}
$$

For reference: ${ }^{\star} \mathrm{p}<0.05 ;{ }^{* *} \mathrm{p}<0.01 ;{ }^{* *} \mathrm{p}<0.001$.

Source: compiled by the author.

Table 4 represents a comparison of evaluations of coefficients when analysing data by means of an ordinary least-square method (pool), fixed effects model (fe) and random effects model (re).

\begin{tabular}{|c|c|c|c|}
\hline Variables & pool & $\mathrm{Fe}$ & re \\
\hline bv & $-0.679^{\star}$ & $0.192^{\star \star}$ & $0.679^{\star *}$ \\
\hline abpr & 0.214 & $1.011^{\star *}$ & $0.214^{*}$ \\
\hline foni & $1.623^{* * *}$ & $-2.235^{\star \star \star}$ & $-1.624^{* * *}$ \\
\hline bss & -0.097 & $0.223^{\star}$ & 1.097 \\
\hline abt & -1.114 & 0.943 & -1.114 \\
\hline $\mathrm{ibm}$ & 0.058 & -0.021 & 0.058 \\
\hline aci & 0.287 & -0.079 & 0.288 \\
\hline bgd & $0.494^{\star}$ & $-1.037^{\star *}$ & $-2.495^{\star}$ \\
\hline bsz & $-5.059^{\star}$ & 3.581 & $-5.059^{*}$ \\
\hline cons & 10.582 & 13.823 & 11.582 \\
\hline
\end{tabular}

Table 4. Regression coefficients for the Russian market

For reference: ${ }^{\star} \mathrm{p}<0.05 ;{ }^{* *} \mathrm{p}<0.01 ;{ }^{* *} \mathrm{p}<0.001$.

Designations: bv - book value of equity; abpr - abnormal profits; foni - difference between the forecast net profit indicator and actual net profit of companies; bv, abpr, foni were taken per a share; bss - percentage of board members holding professional certificates and licenses; abt - average term of board of directors members; ibm - share of independent members on the board of directors; aci - share of independent members in the audit committee; bgd proportion of women on the board of directors; bsz - size of the board of directors; cons - intercept regression term.

Source: compiled by the author.

Use of the multiple imputation provides robust estimators for restoring the variables. At the same time, taking into consideration the proximity of observation points in space and time for other variables standard errors of the model were replaced with robust Newey-West consistency estimates resistant to autocorrelation. 
Table 5. Deterministic (fixed) effects model

\begin{tabular}{|c|c|c|c|c|}
\hline Variables & Coefficient evaluations & Newey-West errors & $\mathbf{t}$ & $\mathbf{P}>|\mathbf{t}|$ \\
\hline bv & $0.192^{\star *}$ & 0.471 & 1.10 & 0.008 \\
\hline abpr & $1.011^{\star *}$ & 1.697 & 0.21 & 0.007 \\
\hline foni & $-2.235^{\star \star \star}$ & 1.216 & -2.53 & 0.000 \\
\hline bss & $0.223^{\star}$ & 0.197 & 0.90 & 0.041 \\
\hline Abt & 0.943 & 2.738 & 0.77 & 0.632 \\
\hline Ibm & -0.021 & 0.139 & -0.54 & 0.828 \\
\hline aci & -0.079 & 0.082 & -2.17 & 0.387 \\
\hline bgd & $-1.037^{\star * *}$ & 0.486 & -0.95 & 0.000 \\
\hline bsz & 3.581 & 2.344 & 2.06 & 0.452 \\
\hline cons & 13.823 & 3.371 & 1.78 & 0.115 \\
\hline
\end{tabular}

For reference: Prob > F = 0.0000.

Designations: bv - book value of equity; abpr - abnormal profits; foni - difference between the forecast net profit indicator and actual net profit of companies; bv, abpr, foni were taken per a share; bss - percentage of board members holding professional certificates and licenses; abt - average term of board of directors members; ibm - share of independent members on the board of directors; aci - share of independent members in the audit committee; bgd - proportion of women on the board of directors; bsz - size of the board of directors; cons - intercept regression term.

Source: compiled by the author.

The conducted tests led to the conclusion that the fixed effects model is the most adequate one out of the three presented models. The Wald test proved an edge over the pooled regression ( $\mathrm{p}$-level $<0.01$ ). In its turn, the Haussmann test rejected the random effects model (p-level $<$ $0.01)$.

The following tested variables turned out to be significant: the book value of equity; abnormal profits, difference between the forecast net profit indicator and actual net profit of companies; percentage of board members holding professional certificates and licenses; and proportion of women on the board of directors (Table 5). We conclude that an average term of board of directors members, share of independent members on the board of directors, share of independent members in the audit committee and size of the board of directors have no impact on share prices dynamics.

The conducted analysis led to the conclusion that share prices of the studied Russian companies is co-directional to the dynamics of the equity book value, abnormal profits, and the percentage of board members holding professional certificates and licenses. Additionally, an inverse dependence between share prices and the difference between the forecast net profit indicator and actual net profit of companies was revealed. The interpretation may be as follows: the more accurate analysts' forecasts on the amount of net profit, the less the difference with its actual value is, i.e. when the amount of corporate net profit surpasses the forecast value the share prices are higher. The negative sign of the coefficient of proportion of women on the board of directors should be explained with a reserve concerning the industrial composition of the selection: $77 \%$ of studied companies belong to extractive industries. This may indicate that in the case of such companies, the market preferred a lower level of gender diversification in the board of directors. Evaluations of obtained regression coefficients are significant at the level of $p<0.001$, when the difference between the forecast net profit indicator and actual net profit of companies is $(-2.24)$, proportion of women on the board of directors is $(-1.04)$. Further, when the equity book value is (0.19), abnormal profits are (1.01) they are significant at the level of $p<0.01$. The coefficient of the percentage of board members holding professional certificates and licenses is (0.22) and significant at the level of $\mathrm{p}<0.05$.

The calculated evaluations of coefficients allow us to plug data of financial indicators from statements for 2019 financial year into the regression equation and obtain the estimated value of share prices of the studied pool of companies for the Ohlson model (Table 6). 
Table 6. Deviations from actual share prices, in \%

\begin{tabular}{|c|c|c|}
\hline Company & Not taking into consideration CG & Taking into consideration CG \\
\hline Acron & -28.2 & -26.0 \\
\hline Alrosa & -31.8 & -9.7 \\
\hline Joint-Stock Financial Corporation System & -33.8 & -22.1 \\
\hline Aeroflot & -30.3 & -14.4 \\
\hline Bashneft & -28.2 & -18.6 \\
\hline Gazprom & -11.6 & -16.6 \\
\hline Evraz & 15.8 & 13.2 \\
\hline Inter RAO & -12.2 & -16.1 \\
\hline Lukoil & -12.2 & -7.2 \\
\hline M Video & -21.9 & -26.1 \\
\hline Magnit & -8.0 & -7.7 \\
\hline Megafon & -17.8 & -3.1 \\
\hline Mechel & 20.3 & -9.8 \\
\hline Magnitogorsk Iron and Steel Works & 3.0 & 3.8 \\
\hline MTS & 4.1 & 8.9 \\
\hline NLMK & -12.9 & -7.9 \\
\hline Novatek & 8.5 & 13.3 \\
\hline Nornickel & -7.3 & -3.6 \\
\hline Polyus & -7.8 & 6.3 \\
\hline Rosneft & -10.3 & -2.6 \\
\hline Rosseti & -8.1 & -12.4 \\
\hline Rostelecom & -29.5 & -19.3 \\
\hline RusHydro & -14.6 & 2.8 \\
\hline Severstal & 8.9 & 2.8 \\
\hline Surgutneftegas & -23.4 & -21.8 \\
\hline Tatneft & -37.1 & -8.1 \\
\hline Uralkali & -24.2 & -30.5 \\
\hline Phosagro & -4.6 & -4.6 \\
\hline Cherkizovo & 6.3 & 2.9 \\
\hline Enel & -21.9 & -34.9 \\
\hline Unipro & -4.9 & -17.8 \\
\hline On average & -12.1 & -9.3 \\
\hline
\end{tabular}

Source: compiled by the author.

For the studied pool of companies the Ohlson model underestimates the equity capital value of Russian companies by $12.1 \%$ (when not taking into consideration corporate governance). The testing of the complete model allowed to reduce the difference up to $9.3 \%$. This may be caused by considering the corporate governance factors. 


\section{Conclusion}

Corporate governance plays an important role in the financial decisions of companies. An adequate evaluation of this factor allows for a reduction in investors' uncertainty. In this paper, a modified model initially offered by James Ohlson was used to assess the company value.

The purpose of this research was to identify key indicators of corporate governance which influence the market value of Russian companies by modifying the Ohlson model. The tasks which helped to achieve the purpose were solved during the research.

The Ohlson model assigns primary importance to corporate performance indicators described in financial statements, however, it provides an opportunity to modify that by approximating the "other information" parameter. The author studied the influence of a combination of complementary factors: forecast analytical data, and corporate governance indicators.

Empirical results show a co-direction of Russian companies' share prices with dynamics of the equity book value, abnormal profits, and percentage of board members holding professional certificates and licenses. At the same time, share prices show an inverse dependence on the difference between the forecast net profit indicator and the actual net profit of companies and on the level of gender diversification in the board of directors.

When stock prices' estimated values were compared according to the modified Ohlson model to their actual values in 2019, it was found that adding corporate governance factors allowed researchers to reduce underestimation from 12.1 to $9.3 \%$.

The obtained results are comparable to those papers which study emerging European markets of Europe, Africa, and Latin America.

This research is the first one of this kind performed for the Russian equities market. As such, there is room for development of the methodology. For further research in this vein, we would like to recommend an analysis of alternative combinations for evaluation of the "other information" parameter, and increase of the number of studied companies and periods.

\section{References}

1. Jensen M., Meckling, W. Theory of the firm: managerial behavior, agency costs and ownership structure. Journal of Financial Economics. 1976;3(4):308-360. DOI: 10.1016/0304-405X(76)90026-X

2. Shuklina M., Kosorukova O. The role of corporate governance in shaping the value of shares and business of a public joint stock company in the modern Russian economy. Imushhestvennye otnoshenija $v$ Rossijskoj Federacii = Property relations in the Russian Federation. 2018;12:6-16. DOI: 10.24411/2072-4098-2018-10121 (In Russ.).
3. Dementyeva A. Corporate governance system in developed countries and in Russia. Menedzhment $v$ Rossii i za rubezhom = Management in Russia and abroad. 2008;3:124-138. (In Russ.).

4. Shevchenko I., Puchkina E., Tolstov N. Shareholders' and managers' interests: collisions in Russian corporations. Jekonomicheskij zhurnal VShJe = HSE Economic Journal. 2019;23(1):118-142. DOI: 10.17323/1813-8691-2019-23-1-118-142 (In Russ.).

5. Gan H., Simerly M. The use of non-financial performance measures: does the strength of corporate governance matter? American Journal of Management. 2019;19(5):10-30. DOI: 10.33423/ajm. v19i5.2626

6. Byron K., Post C. Women on boards of directors and corporate social performance: a meta-analysis. Corporate Governance: an international review. 2016;24(4):428-442. DOI: 10.1111/corg.12165

7. Terjesen S., Couto E., Francisco P. Does the presence of independent and female directors impact firm performance? A multi-country study of board diversity. Journal of Management and Governance. 2016;20(3):447-483. DOI: 10.1007/s10997-014-9307-8

8. Moursli R. The effects of board independence on busy directors and firm value: Evidence from regulatory changes in Sweden. Corporate Governance: an international review. 2020;28(1):23-46. DOI: 10.1111/corg. 12301

9. Rossignoli F., Lionzo A., Buchetti B. Beyond corporate governance reporting: the usefulness of information on board members profiles. Journal of Management and Governance. 2020 (in print). DOI: 10.1007/s10997-020-09502-4

10. Black B., Love I., Rachinsky A. Corporate governance indices and firms' market values: time series evidence from Russia. Emerging Markets Review. 2006;7:361379.

11. Nalivajskij V., Coj R. Assessment of the impact of corporate governance on the market value of Russian companies. Vestnik Sankt-Peterburgskogo gosudarstvennogo universiteta. Serija "Menedzhment" = Vestnik of Saint Petersburg University. Management series. 2006;3:62-84. (In Russ.).

12. Coj R. On influence of corporate governance quality on Russian companies' efficiency. Korporativnye finansy = Journal of Corporate Finance Research. 2013;1(25):112-117. DOI: 10.17323/j.jcfr.20730438.7.1.2013.112-119 (In Russ.).

13. Nazarova V., Kolykhalina A. Effect of the application of internal corporate governance mechanisms on the value of companies with diversification and focusing strategies. Korporativnye finansy = Journal of Corporate Finance Research. 2018;12(3):7-26. DOI: 10.17323/j.jcfr.2073-0438.12.3.2018.7-26 (In Russ.). 
14. Teti E., Dell'Acqua A., Etro L., Resmini F. Corporate governance and cost of equity: Empirical evidence from Latin American companies. Corporate Governance: The International Journal of Business in Society. 2016;16(5);831-848. DOI: 10.1108/CG-022016-0028

15. Ohlson, J. Earnings, book values and dividends in equity valuation. Contemporary Accounting Research. 1995;11(2):661-687. DOI: 10.1111/j.1911-3846.1995. tb00461.x

16. Ohlson J. Earnings, book values, and dividends in equity valuation: an empirical perspective. Contemporary Accounting Research. 2001;18(1):107120. DOI: 10.1506/7TPJ-RXQN-TQC7-FFAE

17. Dechow P., Hutton A., Sloan R. An empirical assessment of the residual income valuation model. Journal of Accounting and Economics. 1999;26(1-3):134. DOI: 10.1016/S0165-4101(98)00049-4

18. Gregory A., Saleh W., Tucker J. A UK test of an inflation-adjusted Ohlson model. Journal of Business Finance \& Accounting. 2005;32(3-4):487-534. DOI: 10.1111/j.0306-686X.2005.00602.x

19. Lee S., Lin C., Chang P. An Ohlson valuation framework for valuing corporate governance: The case of Taiwan. Pacific-Basin Finance Journal. 2011;19:420-434. DOI: 10.1016/j.pacfin.2011.03.003

20. Fiador V. Corporate governance and value relevance of financial information: evidence from the Ghana Stock Exchange. Corporate Governance. 2011;13(2):208-217. DOI: $10.1108 / 14720701311316689$

21. Martínez P., Prior D., Rialp J. The price of stocks in Latin American financial markets: an empirical application of the Ohlson model. International Journal of Business and Finance Research.

2012;6(4):73-85. Available at SSRN: https://ssrn.com/ abstract $=2149183$

22. Brugni T., Neto A., Bortolon P., Goes A. Different levels of corporate governance and the Ohlson valuation framework: the case of Brazil. Corporate Ownership \& Control. 2012;9(2):1-12. URL: https:// ssrn.com/abstract=2207112 (accessed on 25.03.2020).

23. Durán-Vázquez R., Lorenzo-Valdés A., CastilloRamírez C. Effectiveness of corporate finance valuation methods: Piotroski score in an Ohlson model: the case of Mexico. Journal of Economics, Finance and Administrative Science. 2014;19:104-107. DOI: $10.1016 /$ j.jefas.2014.04.003

24. Wang T., Zhang T. The roles of accounting data in equity valuation: evidence from China. China Finance Review International. 2015;5(1):69-87. DOI: 10.1108/ CFRI-07-2013-0084
25. Okafor O., Anderson M., Warsame H. IFRS and value relevance: evidence based on Canadian adoption. International Journal of Managerial Finance. 2016;12(2):136-160. DOI: 10.1108/IJMF-02-20150033

26. Özer G., Çam I. The Role of Human Capital in Firm Valuation: An Application on BIST. Procedia - Social and Behavioral Sciences. 2016;235:168-177. DOI: 10.1016/j.sbspro.2016.11.012

27. Alfraih M. The role of audit quality in firm valuation: evidence from an emerging capital market with a joint audit requirement. International Journal of Law and Management 2016;58(5):575-598. DOI: 10.1108/ IJLMA-09-2015-0049

28. Zhang X. Value relevance of historical information and forecast information in China: empirical evidence based on the Ohlson and Feltham-Ohlson models. Academy of Accounting and Financial Studies Journal. 2016;20(3):14-27.

29. Zulu M., de Klerk M., Oberholster J. A comparison of the value relevance of interim and annual financial statements. South African Journal of Economic and Management Sciences. 2017;20(1):1-11. DOI: 10.4102/sajems.v20i1.1498

30. Temiz H., Güleç Ö. F. Mandatory adoption of IFRS in emerging markets: the case of Turkey. Accounting and Management Information Systems. 2017;16(4):560580. DOI: 10.24818/jamis.2017.04007

31. Velte P. Do women on management board increase fair value relevance? Corporate Governance and Sustainability Review. 2017;1(1):6-16. DOI: 10.22495/ cgsrvli1p1

32. Miralles-Quiros M., Miralles-Quiros J., Arraiano I. Sustainable development, sustainability leadership and firm valuation: differences across Europe. Business strategy and the environment. 2017;26(17):1014- 1028. DOI: 10.1002/bse.1964

33. Tshipa J., Brummer L., Wolmarans H., Du Toit E. The impact of flexible corporate governance disclosures on value relevance. Empirical evidence from South Africa. Corporate Governance. 2018;18(3):369-385. DOI: 10.1108/CG-05-2017-0106

34. Kwon G. Comparative value relevance of accounting information among Asian countries: Focusing on Korea, Japan, and China. Managerial Finance. 2018;44(2);110-126. DOI: 10.1108/MF-07-2017-0261

35. Kouki A. IFRS and value relevance: A comparison approach before and after IFRS conversion in the European countries. Journal of Applied Accounting Research. 2018;19(1):60-80. DOI: 10.1108/JAAR-052015-0041 
36. Rubin D. Multiple imputation after 18+ years. Journal of the American Statistical Association. 1996:91(43):473-489. DOI: 10.2307/2291635

37. Berzon N., Khassanov A. Ohlson model based valuation of companies in European emerging markets. Vestnik Moskovskogo universiteta. Serija 6 Jekonomika. $=$ Moscow University Economics Bulletin. 2019;5:92-115. (In Russ.).

38. Khassanov A. Comparative analysis of the Ohlson model and methods for companies' valuation in Russia, Poland and France. Finansy $i$ biznes $=$ Finance and business. 2019;15(4):105-121. (In Russ.).

39. Baltagi B. Econometric analysis of panel data. New York: John Wiley \& Sons; 1995. 366 p.

40. Ratnikova T., Furmanov K. Panel data analysis and analysis of state duration data. Moscow: Higher School of Economics publishing house; 2014. 373 p. (In Russ.). 